\title{
Spectroscopic Studies on Indian Portland Cement Hydrated with Distilled Water and Sea Water
}

\author{
D. Govindarajan ${ }^{1}$, R. Gopalakrishnan,"* \\ ${ }^{1}$ Department of Physics, Annamalai University, AnnamalaiNagar, 608002, India \\ ${ }^{2}$ Department of Physics, SRM University, SRM Nagar, 603203, India
}

\begin{abstract}
The spectroscopicstudies have been carried out for Indian Portland cement hydrated with distilled and sea water in a water to cement ratio of 0.4. This study aims to analyze the effect of water on Portland cement. FTIR, DTA, XRD and EPR studies were used to characterize the hydration reaction of the cement pastes. Experimental results on setting time, compressive strength are also reported. The unreacted clinker phases and g-factors are calculated. The results indicate that sea water accelerates the cement hydration at early stage but retards in the latter stage of hydration.
\end{abstract}

Keywords Spectroscopic Studies, Cement, Waters, Setting Time, Compressive Strength

\section{Introduction}

Portland cement is a heterogeneous fine grained material consists of four main solid phases namely Tricalcium Silicate $\left(\mathrm{C}_{3} \mathrm{~S}\right)$, Dicalcium Silicate $\left(\mathrm{C}_{2} \mathrm{~S}\right)$, Tricalcium Aluminate $\left(\mathrm{C}_{3} \mathrm{~A}\right)$, TetracalciumAlumino Ferrite $\left(\mathrm{C}_{4} \mathrm{AF}\right)$. During hydration of cement, Calcium Silicate Hydrate (C-S-H) gel and calcium hydroxide $\left(\mathrm{Ca}(\mathrm{OH})_{2}\right)$ are formed from silicates phases and ettringite $(\mathrm{AFt})$, monosulphate $(\mathrm{AFm})$ are formed from aluminate phases[1]. C-S-H, a major hydration product is the main strength forming phase in the cement paste. $\mathrm{Ca}(\mathrm{OH})_{2}$ is a crystalline, isostructural with natural mineral of Portlandite. The cement hydration reactions are

$$
\begin{aligned}
& 2\left(3 \mathrm{CaO} \cdot \mathrm{SiO}_{2}\right)+6 \mathrm{H}_{2} \mathrm{O} \rightarrow 3 \mathrm{CaO} \cdot 2 \mathrm{SiO}_{2} \cdot 3 \mathrm{H}_{2} \mathrm{O}+3 \mathrm{Ca}(\mathrm{OH})_{2}(1) \\
& \text { Tricalcium water C-S-H Calcium hydroxide } \\
& \text { Silicate } \\
& 2\left(2 \mathrm{CaO} \cdot \mathrm{SiO}_{2}\right)+4 \mathrm{H}_{2} \mathrm{O} \rightarrow 3 \mathrm{CaO} \cdot 2 \mathrm{SiO}_{2} \cdot 3 \mathrm{H}_{2} \mathrm{O}+\mathrm{Ca}(\mathrm{OH})_{2}(2) \\
& \text { Dicalcium water C-S-H Calcium hydroxide } \\
& \text { Silicate } \\
& 3 \mathrm{CaO} \cdot \mathrm{Al}_{2} \mathrm{O}_{3}+3 \mathrm{CaSO}_{4}+32 \mathrm{H}_{2} \mathrm{O} \rightarrow \mathrm{Ca}_{6} \mathrm{Al}_{2}\left(\mathrm{SO}_{4}\right)_{3}(\mathrm{OH})_{12} \cdot 26 \mathrm{H}_{2} \mathrm{O}(3) \\
& \text { Tricalcium gypsum water ettringite } \\
& \text { Aluminate } \\
& \mathrm{Ca}_{6} \mathrm{Al}_{2}\left(\mathrm{SO}_{4}\right)_{3}(\mathrm{OH})_{12} \cdot 26 \mathrm{H}_{2} \mathrm{O}+2\left(3 \mathrm{CaO} \cdot \mathrm{Al}_{2} \mathrm{O}_{3}\right)+4 \mathrm{H}_{2} \mathrm{O} \\
& \text { ettringite Tricalcium aluminate water } \\
& \rightarrow \mathrm{CaO} \cdot \mathrm{Al}_{2} \mathrm{O}_{3} \cdot \mathrm{CaSO}_{4} \cdot 12 \mathrm{H}_{2} \mathrm{O} \\
& \text { monosulphate }
\end{aligned}
$$

Many Spectroscopic methods, Setting time and Compressive strength have been used in various studies of cement hydration for a number of years[2-5].

Cement notations: $\mathrm{C}=\mathrm{CaO} ; \mathrm{S}=\mathrm{SiO}_{2} ; \mathrm{H}=\mathrm{H}_{2} \mathrm{O} ; \mathrm{C}_{3} \mathrm{~S}=$

* Corresponding author:

gopalsrmphysics@gmail.com (R. Gopalakrishnan)

Published online at http://journal.sapub.org/fs

Copyright $(2011$ Scientific \& Academic Publishing. All Rights Reserved
$3 \mathrm{CaO} . \mathrm{SiO}_{2} ; \mathrm{C}_{2} \mathrm{~S}=2 \mathrm{CaO} . \mathrm{SiO}_{2} ; \mathrm{C}_{3} \mathrm{~A}=3 \mathrm{CaO} . \mathrm{Al}_{2} \mathrm{O}_{3} ; \mathrm{C}_{4} \mathrm{AF}=$ $4 \mathrm{CaO} \cdot \mathrm{Al}_{2} \mathrm{O}_{3} \cdot \mathrm{Fe}_{2} \mathrm{O}_{3} ; \mathrm{CH}=\mathrm{Ca}(\mathrm{OH})_{2}$

Presently, all over the world, the construction of buildings near sea shores are increased in numbers due to Tsunami. Moreover, the intrusions of sea water range in the earth are also increases in several kilometres. Hence the urge for more research work on behavior of sea water treated cement is needed.

The influence of different waters on cement was studied by Barathan et al.,[6] with the help of X-band Microwave technique. They have reported that the cement mixing with sea water has the highest value of $\varepsilon$ and $\sigma$ and then ground water and then distilled water. Ghorabet al.,[7] pointed that the sea water accelerates cement hydration due to the chloride ions and hence early setting. Ganjian and Pouya[8] and Kaushik and Islam[9] states that the sea water initially accelerate the cement hydration and hence an early strength. Huseyin Yigiter et al.,[10] was investigated the effects of cement type, cement content and water to cement ratio level on the sea water resistance of concrete. According to Manu Santhanam et al.,[11] microstructure and thermal analysis investigation confirm that sulfate attack in Portland cement mortars performed better in seawater solution compared to ground water solution.

As far as we are aware, spectroscopic studies on hydration of Indian cement with distilled water and sea water are less and especially no EPR studies on hydration of cement treated with sea water. In this study, the author discusses the results obtained from spectroscopic studies on Indian cement treated with distilled water (DW) and sea water (SW) at different hydration time intervals.

\section{Materials and Methods}


Table 1. Content of solvents of different waters $(\mu \mathrm{g} / \mathrm{g})$

\begin{tabular}{|c|c|c|c|c|c|c|c|}
\hline Water & Total dissolved solvents & Total hardness & Chlorine & Magnesium & Calcium & Sulphur & Sodium \\
\hline DW & 45 & 4 & - & 1 & 2 & - & - \\
\hline SW & 30500 & 1060 & 16400 & 1080 & 272 & 5.80 & 9100 \\
\hline
\end{tabular}

A commercial Portland cement (PC) was used and subjected to chemical analysis using standard procedure suggested by ASTM and found the ingredients in percent as follows: $\mathrm{CaO}$ 63.32; $\mathrm{SiO}_{2} 21.70 ; \mathrm{Al}_{2} \mathrm{O}_{3}$ 5.40; $\mathrm{Fe}_{2} \mathrm{O}_{3} 3.40$; $\mathrm{MgO} 2.09 ; \mathrm{MnO} 0.12 ; \mathrm{SO}_{3} 2.10$; Loss on ignition 0.79 and Insoluble residue 1.08 . The distilled water and sea water was analyzed using standard procedure and given in Table 1.

The pastes were prepared by mixing the cement with distilled water and sea water in water to cement ratio of 0.4 . The samples were thoroughly mixed using glass rod for two minutes and then allowed to hydrate in air-tight plastic containers. The hydrations were stopped at different time intervals viz., 1 hour, 1 day, 1 week and 4 weeks by a consecutive soaking in acetone. To remove water content the hydrated cement pastes were oven-dried at $105^{\circ} \mathrm{C}$ for 1 hour[12]. The samples hydrated for more than 1 day were cured properly. The dried samples were powdered using agate mortar for FTIR, DTA, XRD and EPR studies.

The Fourier transform infrared measurements were recorded with a Nicolet-Avatar 360 model FTIR spectrometer using the $\mathrm{KBr}$ pellets technique. The Thermal curves of the OPC pastes were taken in a Perkin Elmer thermal analyzer. A total of $10-15 \mathrm{mg}$ of the samples was heated in a platinum crucible in air atmosphere up to $1000^{\circ} \mathrm{C}$ in a heating rate of $10^{\circ} \mathrm{C} / \mathrm{min}$. Compositional changes occur in the hydrated OPC pastes were identified by X-ray diffraction with $\mathrm{CuK} \alpha$ radiation for Bragg's angles between 5 and $70^{\circ}$ with the scan rate of 0.1 to 120 degrees in $2 \theta / \mathrm{min}$. EPR spectra were recorded using JEOL JES-TE100 ESR Spectrometer operating at X-band frequencies, having a $100 \mathrm{KHz}$ field modulation and DPPH is used as the standard reference for magnetic field correction. Setting time has been measured on DW and SW cement paste and compressive strength of the cement with DW and SW at different hydration times period were determined[13] and reported in Table 2.

Table 2. Setting time and Compressive strength of cement treated with DW and SW

\begin{tabular}{|c|c|c|c|c|c|c|}
\hline \multirow{2}{*}{ Sample } & \multirow{2}{*}{ Water } & \multicolumn{2}{|c|}{$\begin{array}{c}\text { Setting time } \\
\text { (h:min) }\end{array}$} & \multicolumn{3}{|c|}{ Compressive strength (MPa) } \\
\cline { 3 - 7 } & & Initial & Final & 1 day & 1 week & 4 weeks \\
\hline \multirow{2}{*}{ OPC } & DW & 5.05 & 6.50 & 10.4 & 32.6 & 47.7 \\
& SW & 4.10 & 6.20 & 13.1 & 34.4 & 33.1 \\
\hline
\end{tabular}

\section{Results and Discussion}

\subsection{FTIR Results}

The FTIR spectrum of the anhydrous Portland cement Fig. 1(a) shows a sharp band at $3630 \mathrm{~cm}^{-1}$ associated to $\mathrm{O}-\mathrm{H}$ stretching vibrations of portlandite $\left(\mathrm{Ca}(\mathrm{OH})_{2}\right)$ and the peaks at 3410 and $1610 \mathrm{~cm}^{-1}$ are correspond to stretching and bending modes of water of crystallization particularly from gypsum. The carbonates peak at $1425 \mathrm{~cm}^{-1}, 717 \mathrm{~cm}^{-1}$ and 875 $\mathrm{cm}^{-1}$ are observed due to the reactions of atmospheric $\mathrm{CO}_{2}$ with calcium hydroxide. The triplet bands appearing at $1100-1160 \mathrm{~cm}^{-1}$ are due to $v_{3}$ modes of $S O_{4}^{2-}$ and the week bands at $659 \mathrm{~cm}^{-1}$ and $600 \mathrm{~cm}^{-1}$ are due to $v_{4}$ modes of $S_{4}^{2-}$. The strong band at $919 \mathrm{~cm}^{-1}$ is due to $\mathrm{Si}-\mathrm{O}$ asymmetric stretching vibration of $\mathrm{C}_{3} \mathrm{~S}$ and/or $\mathrm{C}_{2} \mathrm{~S}$. Out of plane Si-O bending $\left(v_{4}\right)$ and in-plane Si-O bending $\left(v_{2}\right)$ are observed at $525 \mathrm{~cm}^{-1}$ and $455 \mathrm{~cm}^{-1}$ respectively. The band assignments are in good agreement with those reported in the previous studies[14-16].

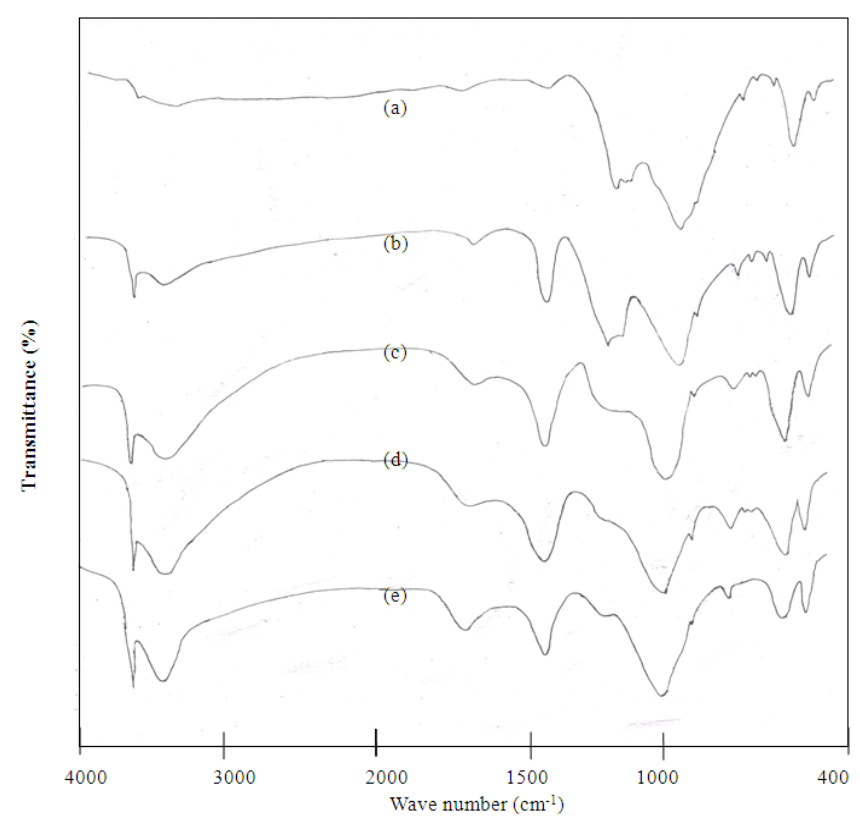

Figure 1. FTIR spectra of (a) Anhydrous cement and Distilled water hydrated cement paste at (b) 1 hour (c) 1 day (d) 1 week (e) 4 weeks

From the FTIR spectra of DW treated cement paste (Fig. 1(b-e)), as hydration progresses, the following bands are observed i) the intensity of the band at $3630 \mathrm{~cm}^{-1}$ increases indicating liberation of more $\mathrm{Ca}(\mathrm{OH})_{2}$. ii) the broad band at $3440 \mathrm{~cm}^{-1}$ are intensified with hydration, indicating that the increase of hydrated products associated with water. iii) the strong asymmetric stretching Si-O band $\left(v_{3}\right)$ is shifted to high frequencies centered at $970 \mathrm{~cm}^{-1}$ with hydration indicates that the formation of C-S-H[17]. The decrease and increase in intensities of the out-of-plane and in-plane Si-O bending vibrations are occur in significant changes with hydration and it indicates that the polymerization of $\mathrm{SiO}_{4}^{4-}$ units in cement.

For sea water treated cement pastes (Fig. 2), the same frequency assignment holds good as that of DW, but there is variation in intensities are observed. The shifting of $v_{3} \mathrm{Si}-\mathrm{O}$ band and variation in intensity of $v_{4}$ and $v_{2} \mathrm{Si}-\mathrm{O}$ bands are 
enhanced by SW are observed in early age. Up to 1 week, the intense sulfate band $\left(\mathrm{SO}_{4}^{2-}\right)$ at $1100-1160 \mathrm{~cm}^{-1}$ are observed and it implies that $\mathrm{SW}$ enhance the $\mathrm{AF}_{\mathrm{t}}$ formation than $\mathrm{DW}$. The observed variation in intensities of the band at 919-970 $\mathrm{cm}^{-1}, 525 \mathrm{~cm}^{-1}$ and $455 \mathrm{~cm}^{-1}$ are higher and occur from early age onwards. This indicates that the initial reactions are faster due to the higher amount of chloride and sulfate ions present in the sea water[6,7]. At 4 weeks, the intensity of the band observed at $970 \mathrm{~cm}^{-1}, 525 \mathrm{~cm}^{-1}$ and $455 \mathrm{~cm}^{-1}$ are less when compared to 1 week hydration. This may be due to disappearance of mineral contents in sea water. The above fact that increases the strength up to 1 week and slightly decreases at 4 weeks. Hence it is clear that SW accelerate the cement hydration at early stage but in latter stage slightly retarded.

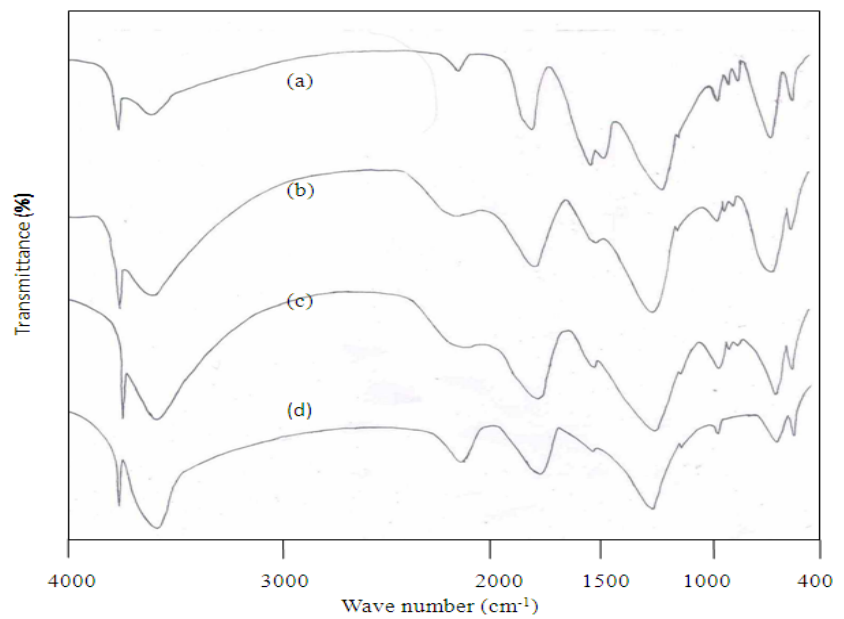

Figure 2. FTIR spectra of Sea water hydrated cement paste at (a) 1hour (b) 1 day (c) 1 week (d) 4 weeks

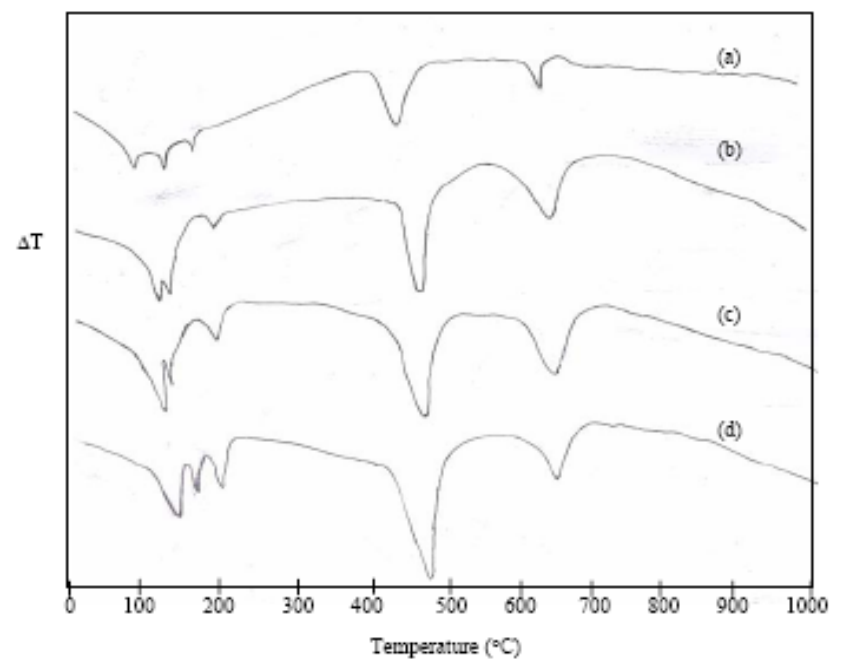

Figure 3. DTA curves of Distilled water hydrated cement paste at (a) 1 hour (b) 1 day (c) 1 week (d) 4 weeks

\subsection{DTA Results}

Fig. 3 shows the DTA thermograms of OPC treated with DW at different hydration periods. At 1 hour hydrated cement paste, five endothermic peaks are observed. The peak at $98^{\circ} \mathrm{C}$ and $160^{\circ} \mathrm{C}$ are due to the presence of gypsum. The endothermic peak observed at $130^{\circ} \mathrm{C}$ represents decomposition of ettringite. The fourth peak at $450^{\circ} \mathrm{C}$ represents the decomposition of calcium hydroxide. The fifth endothermic peak at $670^{\circ} \mathrm{C}$ is due to decomposition of calcium carbonate[18]. At 1 day, the peak at $98^{\circ} \mathrm{C}$ and $160^{\circ} \mathrm{C}$ are disappearing. This implies that the reaction of gypsum is almost exhausted. Further at 1 day, endothermic curve appears at around $115^{\circ} \mathrm{C}$ and $180^{\circ} \mathrm{C}$ indicates the formation of C-S-H and monosulphate. With progress of hydration, the endotherms due to C-S-H, monosulphate and $\mathrm{Ca}(\mathrm{OH})_{2}$ are increased in size (Fig. 3) are observed and also slightly shifting to a higher temperature. At 4 weeks, the intensity of the calcium carbonate endotherm is decreased. This is due to the reaction of $\mathrm{CO}_{2}$ with $\mathrm{C}-\mathrm{S}-\mathrm{H}$ and $\mathrm{Ca}(\mathrm{OH})_{2}$ according to the following equation:[17]

$$
\begin{gathered}
\mathrm{C}-\mathrm{S}-\mathrm{H}+\mathrm{CO}_{2} \rightarrow \mathrm{CaCO}_{3}+\text { silica }+\mathrm{H}_{2} \mathrm{O} \\
\mathrm{Ca}(\mathrm{OH})_{2}+\mathrm{CO}_{2} \rightarrow \mathrm{CaCO}_{3}+\mathrm{H}_{2} \mathrm{O}
\end{gathered}
$$

The main features of the SW treated paste (Fig. 4) when compared to DW treated paste are i) the peak intensities are increases and slightly shifts to higher temperature up to 1 week due to the presence of mineral ions. ii) At 4 weeks, peak intensities are decreased due to the disappearance of mineral ions. These findings are totally agreed with FTIR results.

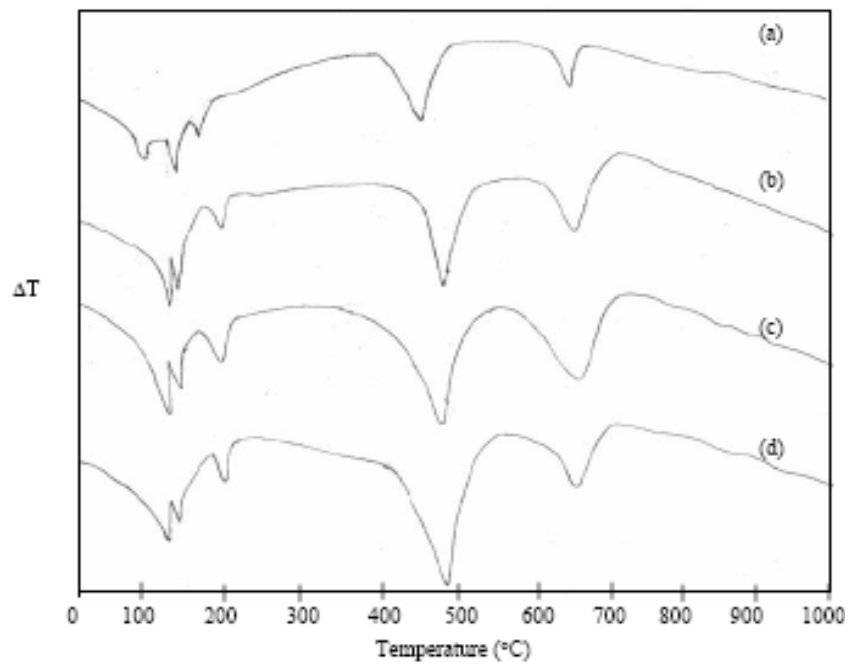

Figure 4. DTA curves of Sea water hydrated cement paste at (a) 1hour (b) 1 day (c) 1 week (d) 4 weeks

\subsection{XRD Results}

Fig. 5(a) shows the XRD pattern of anhydrous cement. The spectrum indicated the presence of gypsum $(2 \theta=$ $\left.11.70^{\circ}\right)$, tricalcium silicate $\left(2 \theta=32.20^{\circ}, 51.50^{\circ}, 62.40^{\circ}\right)$, dicalcium silicate $\left(2 \theta=32.50^{\circ}, 56.15^{\circ}\right)$, tricalcium aluminate $\left(2 \theta=26.51^{\circ}\right)$, tetracalciumaluminoferrite $\left(2 \theta=44.10^{\circ}\right)$ and $\mathrm{CaO}\left(2 \theta=37.60^{\circ}\right)$ respectively are coincide with previous reports[19-21].

The XRD patterns of the cement hydrated with DW at 1 hour, 1 day, 1 week and 4 weeks are shown in Fig. 5(b-e).At 1 hour, ettringite $\left(2 \theta=9.10^{\circ}, 23.10^{\circ}, 41.25^{\circ}\right)$ and $\mathrm{Ca}(\mathrm{OH})_{2}\left(2 \theta=18.10^{\circ}, 33.57^{\circ}\right)$ crystallized phases are observed. At 1 day hydrationC-S-H $\left(2 \theta=29.50^{\circ}\right)$ and mono- 
sulphate $\left(2 \theta=56.64^{\circ}\right)$ phases are identified. The four clinker phases $\left(\mathrm{C}_{3} \mathrm{~S}, \mathrm{C}_{2} \mathrm{~S}, \mathrm{C}_{3} \mathrm{~A}, \mathrm{C}_{4} \mathrm{AF}\right)$ decreases with increasing hydration time and consequently C-S- $\mathrm{H}, \mathrm{Ca}(\mathrm{OH})_{2}$ crystalline phase intensities are increases. The $\mathrm{CaCO}_{3}\left(2 \theta=38.68^{\circ}\right)$ peak is observed for all hydration time, due to the atmospheric carbon dioxide during grinding and preparation of samples[22].These results are confirmed through FTIR, DTA.

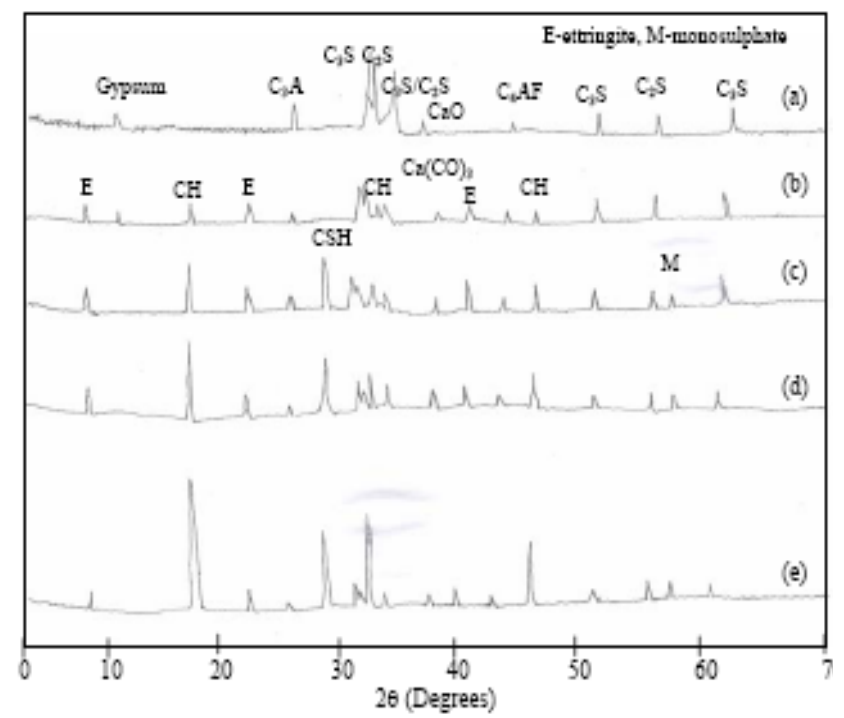

Figure 5. XRD pattern of (a) Anhydrous cement and Distilled water hydrated cement paste at (b) 1 hour (c) 1 day (d) 1 week (e) 4 weeks

The XRD pattern of SW treated cement pastes at various hydration time intervals are shown in Fig. 6. The products formed in SW treated cement are similar to that of DW treated cement, but higher amount of ettringite are observed in the initial stage. The rate of increase of C-S-H and $\mathrm{Ca}(\mathrm{OH})_{2}$ intensities and the corresponding decrease of $\mathrm{C}_{3} \mathrm{~S}$ and $\mathrm{C}_{2} \mathrm{~S}$ intensities are higher when compared to DW treated cement. This is due to the presence of mineral ions and hence accelerates the hydration.

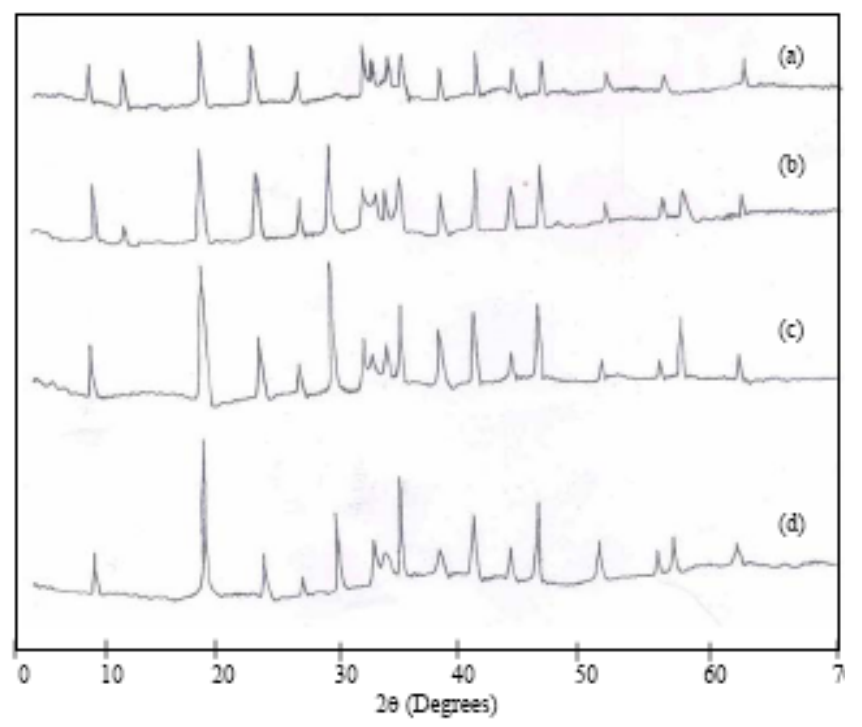

Figure 6. XRD pattern of Sea water hydrated cement paste at (a) 1hour (b) 1 day (c) 1 week (d) 4 weeks
The percentage of unreacted cement clinker $\left(\mathrm{C}_{3} \mathrm{~S}(2 \theta=\right.$ $\left.\left.32.2^{\circ}\right), \mathrm{C}_{2} \mathrm{~S}\left(2 \theta=32.5^{\circ}\right)\right)$, in different hydration time intervals for DW, SW treated pastes were evaluated according to the method described by Montgomery etal.,[23].The results are given in Table 3.

Table 3. The percentages of unreacted cement clinker $\left(\mathrm{C}_{3} \mathrm{~S}, \mathrm{C}_{2} \mathrm{~S}\right)$ remaining in hydrated cement treated with DW and SW

\begin{tabular}{|c|c|c|c|c|}
\hline \multirow{2}{*}{$\begin{array}{c}\text { Hydration } \\
\text { Period }\end{array}$} & \multicolumn{2}{|c|}{$\mathrm{C}_{3} \mathrm{~S}$} & \multicolumn{2}{c|}{$\mathrm{C}_{2} \mathrm{~S}$} \\
\cline { 2 - 5 } & $\mathrm{DW}$ & $\mathrm{SW}$ & $\mathrm{DW}$ & $\mathrm{SW}$ \\
\hline 1 hour & 85.40 & 74.21 & 89.21 & 77.24 \\
\hline 1 day & 69.45 & 67.45 & 75.24 & 71.21 \\
\hline 1 week & 42.23 & 40.45 & 57.40 & 54.51 \\
\hline 4 weeks & 19.32 & 22.45 & 18.34 & 21.45 \\
\hline
\end{tabular}

The results shows that the $\%$ of unreacted $\mathrm{C}_{3} \mathrm{~S}$ and $\mathrm{C}_{2} \mathrm{~S}$ are decreases in DW treated cement with hydration time and this value in the present work are agreed with those reported by[17].For SW treated cement, the rate of decrease in percentage of unreacted $\mathrm{C}_{3} \mathrm{~S}$ are higher up to 1 week when compared to DW cement paste but at 4 weeks the rate of decrease of percentage of unreacted $\mathrm{C}_{3} \mathrm{~S}$ and $\mathrm{C}_{2} \mathrm{~S}$ arelower. This trend shows at the well evidence for SW accelerate the cement hydration in the early stage and retard in the latter stage.

\subsection{EPR Results}

The EPR spectra OPC paste mixing with DW and SW is shown in Figs. 7 and 8.For all samples the experimental parameters are the same and g-values are obtained from the equation $g=h v / \beta B$, where $\beta$ is the Bohr magneton, $h$ is the Planck's constant, $v$ is the frequency and B is the center field at which the resonance occurred[24]. The g-value is main key parameter in identifying paramagnetic results in a particular symmetry. The g-values have been calculated for both $\mathrm{Fe}(\mathrm{III})$ and $\mathrm{Mn}(\mathrm{II})$ signals of cement pastes at different hydration period and are shown in Figs. 9 and 10(Table 4).

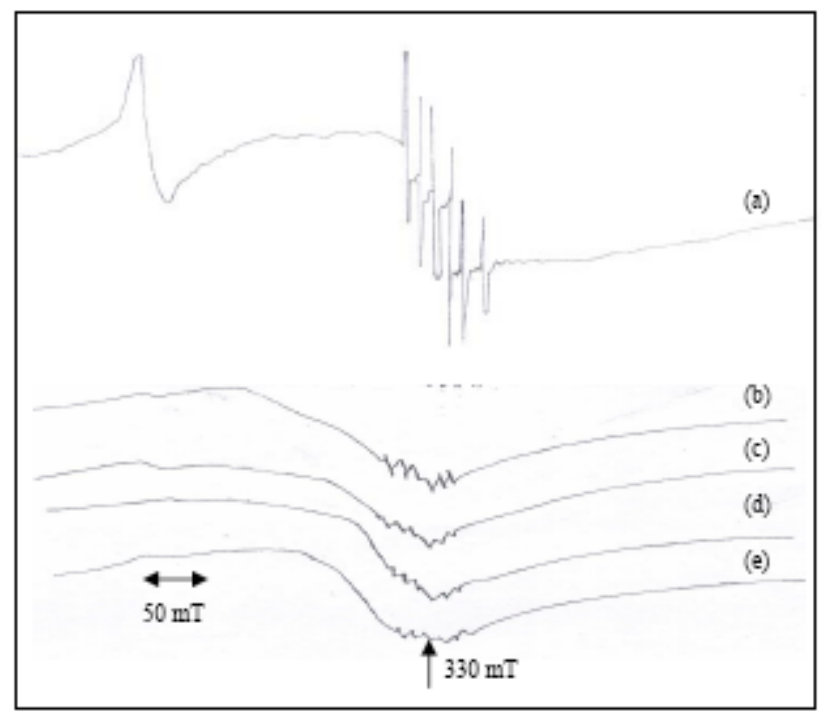

Figure 7. EPR spectra of (a) Anhydrous cement (Frequency $=9.39624$ $\mathrm{GHz}$ ) and Distilled water hydrated cement paste at (b) 1 hour (Frequency $=$ $9.39723 \mathrm{GHz}$ ) (c) 1 day (Frequency $=9.37654 \mathrm{GHz}$ ) (d) 1 week (Frequency $=9.39465 \mathrm{GHz})(\mathrm{e}) 4$ weeks $($ Frequency $=9.39873 \mathrm{GHz})$ 


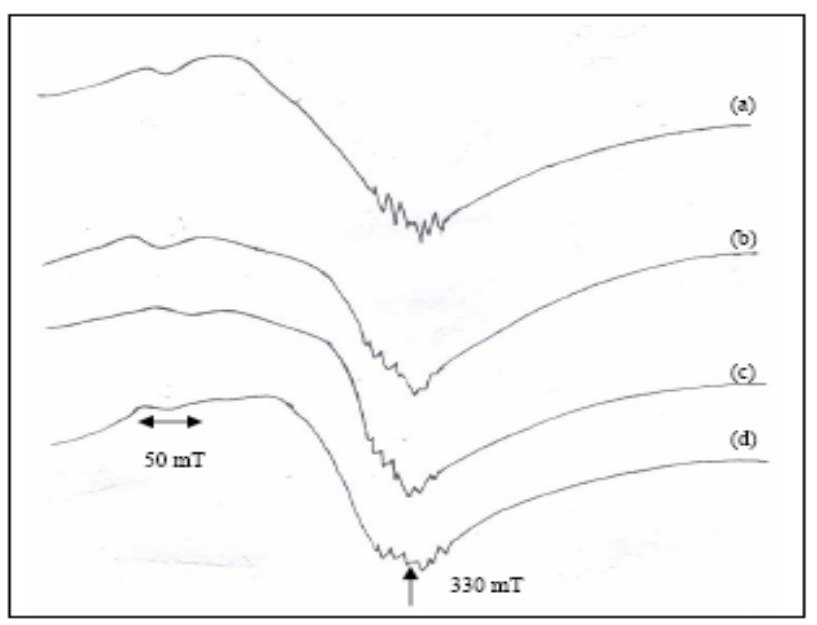

Figure 8. EPR spectra of Sea water hydrated cement paste at (a) 1hour $($ Frequency $=9.39812 \mathrm{GHz})(\mathrm{b}) 1$ day $($ Frequency $=9.37731 \mathrm{GHz})(\mathrm{c})$ 1 week $($ Frequency $=9.39654 \mathrm{GHz})(\mathrm{d}) 4$ weeks $($ Frequency $=9.39751 \mathrm{GHz})$

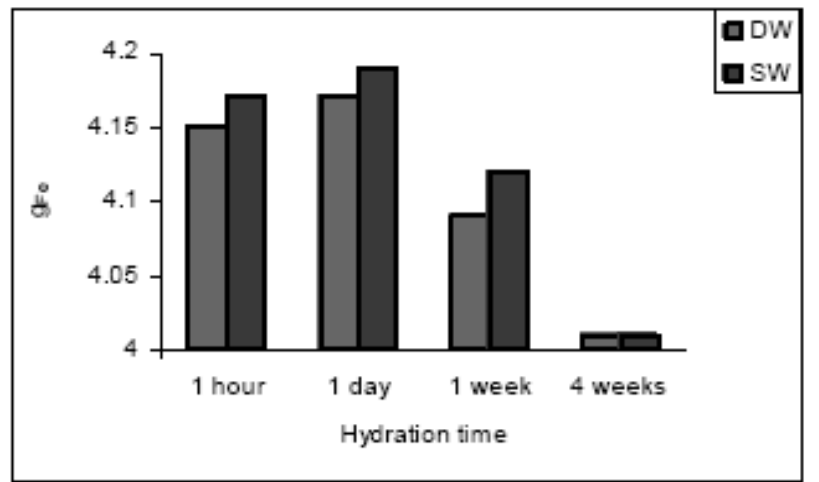

Figure 9. $\mathrm{g}$ velues $v s$ hydration time of cement paste treated with DW and SW

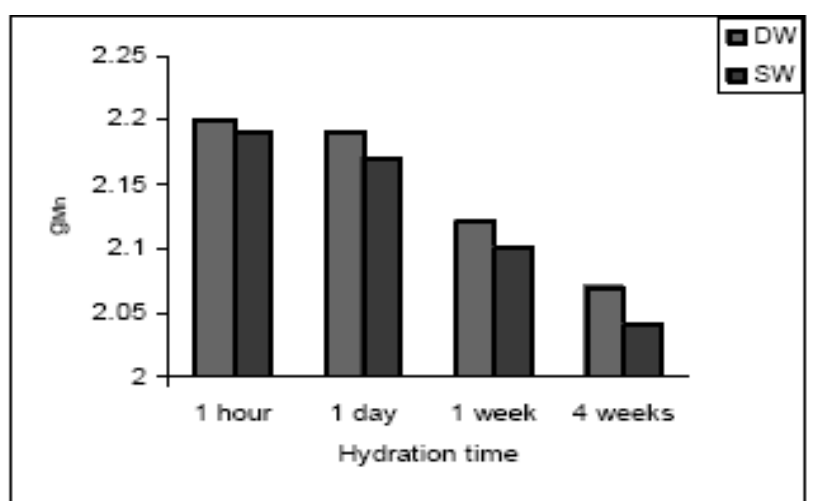

Figure 10. $g$ values $v s$ hydration time of cement paste treated with DW and SW

Table 4. g-values of the cement paste treated with DW and SW

\begin{tabular}{|c|r|r|r|r|}
\hline \multirow{2}{*}{$\begin{array}{c}\text { Hydration } \\
\text { Period }\end{array}$} & \multicolumn{2}{|c|}{$\mathrm{g}_{\mathrm{Fe}}$} & \multicolumn{2}{c|}{$\mathrm{g}_{\mathrm{Mn}}$} \\
\cline { 2 - 5 } & $\mathrm{DW}$ & $\mathrm{SW}$ & $\mathrm{DW}$ & $\mathrm{SW}$ \\
\hline Anhydrous & 4.13 & 4.13 & 2.14 & 2.14 \\
\hline 1 hour & 4.15 & 4.17 & 2.20 & 2.19 \\
\hline 1 day & 4.17 & 4.19 & 2.19 & 2.17 \\
\hline 1 week & 4.09 & 4.12 & 2.12 & 2.10 \\
\hline 4 weeks & 4.01 & 4.01 & 2.07 & 2.04 \\
\hline
\end{tabular}

From the anhydrous cement (Fig. 7(a)), the broad and intense EPR signal at $\mathrm{g}=4.13$ pertains to the $\mathrm{Fe}(\mathrm{III})$ ion, which is usually present in cement.This signal arises from oxidation state of $\mathrm{Fe}(\mathrm{III})$, which is in a tetragonally distorted octahedral environment, surrounded by six ligands. In addition, a sextet having a g-value of 2.14 and a hyperfine coupling constant of $9.1 \mathrm{mT}$ is also present. This is due to $\mathrm{Mn}(\mathrm{II})$, replacing $\mathrm{Ca}(\mathrm{II})$ ions in the lattice positions of calcium hydroxide. The observed values in the present work also agree with those reported by Bruckner et al.[24].

For DW hydrated cement paste, both $\mathrm{g}_{\mathrm{Fe}}$ and $\mathrm{g}_{\mathrm{Mn}}$ values are found to increase from anhydrous cement to 1 day hydrated cement. During hydration, ettringite is the first hydration products in cement paste, rich in iron content, produced through the consumption of gypsum by $\mathrm{C}_{3} \mathrm{~A}$ and $\mathrm{C}_{4} \mathrm{AF}$. Due to increase in iron content, the resonance line due to $\mathrm{Fe}$ (III) species becomes broader and distributed over the whole range of spectrum. The broad signal is attributed to magnetically ordered $\mathrm{Fe}-\mathrm{O}-\mathrm{Fe}$ species with ferri/ferro, or anti ferromagnetic behavior. The high $\mathrm{g}_{\mathrm{Fe}}(=4.17)$ value of the OPC paste is caused by $\mathrm{Fe}$ (III) ions in sites of strong rhombic distortion[24]. From Fig. 7, the observed sextet ( $\mathrm{g}_{\mathrm{Mn}}$ $=2.14$ ) is due to $\mathrm{Mn}(\mathrm{II})$ impurity ions and incorporated into Ca lattice positions of $\mathrm{Ca}(\mathrm{OH})_{2}$ formed during hydration[3]. The $\mathrm{g}_{\mathrm{Mn}}$ values gradually increases up to 1 day due to less incorporation of formed $\mathrm{Mn}(\mathrm{II})$ in $\mathrm{Ca}(\mathrm{OH})_{2}$. Since before 1 day the formation of $\mathrm{Ca}(\mathrm{OH})_{2}$ isvery less. At 1 day, the $\mathrm{Ca}(\mathrm{II})$ concentration reaches the saturation level and the crystallization of calcium hydroxide occurs and C-S-H gel is formed and the availability of ions and water is reduced. Hence after 1 day, the g-factor for $\mathrm{Fe}$ and $\mathrm{Mn}$ values has gradually decreased. This is because these two ions are responsible for the hardening of the main silicate component. It may be that the mobility ofthis particular silicate aggregate is reflected in the vigorous changes in polycrystalline quasi-isotropic character of electron paramagnetic spectra of $\mathrm{Fe}(\mathrm{III})$, $\mathrm{Fe}(\mathrm{II})$ ions to the anisotropic. Also the decreased g-factor values reflect the structural changes of $\mathrm{Fe}(\mathrm{III})$ ions to $\mathrm{Fe}(\mathrm{II})$ ions. This structural change has affected the spin Hamiltonian parameters $[23,26]$. The availability of $\mathrm{Fe}$ (III) ions and $\mathrm{Mn}(\mathrm{II})$ ions are reduced and hence the g-factor values have gradually decreased on standing up to 4 weeks. Due to accelerating nature of $\mathrm{SW}$, the $\mathrm{g}_{\mathrm{Fe}}$ values are higher at 1 hour onwards when compared to DW. The formation of the $\mathrm{Ca}(\mathrm{OH})_{2}$ starts at early stage and the incorporation of $\mathrm{Mn}$ (II) ions in $\mathrm{Ca}(\mathrm{OH})_{2}$ starts at 1 hour onwards and hence $\mathrm{g}_{\mathrm{Mn}}$ values are gradually decreased on standing up to 4 weeks.

\subsection{Setting Time and Compressive Strength Results}

From the Table 2, the setting time of SW treated cement paste are shorter than those of DW treated cement paste. Moreover the sea water treated cement shows higher strength compared to distilled water treated cement up to 1 week and at 4 weeks the compressive strength are decreased. This is because that the following reason i) in the initial stage, sea water accelerates the reaction but in the latter stage the reaction is slower due to reduction in chloride and sulphate ions[6,7] ii) the reaction of $\mathrm{C}_{2} \mathrm{~S}$ with sea water occurs earlier 
and hence in the later stage strength decreases when compared to DW treated samples. These results are very well agreed with FTIR, DTA and XRD.

\section{Conclusions}

This paper describes spectroscopic studies on Indian Portland cement mixed with distilled and sea water. The following conclusion can be drawn from this study.

1. The results indicate that spectroscopic studies can be effectively used as a powerful tool in delineating the complexities of chemical reactions in cement hydration.

2. The contents of mineral ions in sea water accelerate the Portland cement hydration especially at early ages. FTIR, DTA, XRD and EPR studies corroborated these results.

3. EPR is a good tool to detect very small concentration s of $\mathrm{Fe}(\mathrm{III})$ and $\mathrm{Mn}(\mathrm{II})$ ions present in cement. g-factor values are confirmation of the well known accelerating effect of sea water in cement hydration.

4. The effect of sea water in cement reduces the setting time, enhances the hydration and hence consecutive strength development at early stage but slightly retards in latter strength.

5. The utility of sea water for preparing paste may be considered after studying about its long term reaction. Shrinkage properties, corrosion resistance and adhesion capacity are needed to be studied in the future.

\section{REFERENCES}

[1] NEVILLEA M, BROOKS J J. Concrete Technology (Addison Wesley Longman Ltd)[B]. (1987)

[2] WIELANDE, DÄHNR, VESPAM, LOTHENBACHB.Micro spectroscopicinvestigation of $\mathrm{Al}$ and $\mathrm{S}$ speciation in hardened cement paste[J].Cement Concrete Research, 2010, 40(6): 875-884

[3] BRUCKNERA, LUCKR, WIEKERW, WINKLER A, ANDREAE $C$, MEHNER $H$. Investigation of redox reactions proceeding during the hardening process of sulfide containing cement[J]. Cement Concrete Research, 1992, 22: 1161-1169

[4] CAIJUN S. Effect of properties of concrete on its electrical conductivity and the rapid chloride permeability test results[J]. Cement Concrete Research, 2004, 34: 537-545

[5] POON C, AZHAR S, ANSON M, WONG Y. Performance of metakaolin concrete at elevated temperatures[J].Cement Concrete Composites, 2004, 25:83-89.

[6] BARATHAN S, GOVINDARAJAND, SIVAKUMAR G, RAGHUK. Microwave study of hydration of cement with different waters $[\mathrm{J}]$. Indian Journal of Pure and Applied Physics, 2006, 44 : 334-338

[7] GHORAB H Y, HILALM S, KISHARE A. Effect of mixing and curing water on the behaviour of cement pastes and concrete Part. 1[J]. Cement Concrete Research,1989, 19: $868-878$
[8] GANJIAN E and SADEGHI PH. Effect of magnesium and sulfate ions on durability of silicafume blended mixes exposed to the sea water. Cement Concrete Research, 2005, 35: $1332-1338$

[9] KAUSHIK S.K and ISLAMS. Suitability of seawater for mixing structural concrete exposed to a marine environment[J]. Cement Concrete. Composites, 1995, 17; 177-184

[10] YIGITER H, YAZICI H and AYDIN S. Effect of cement type, water/cementratio and cement content on seawater resistance of concrete[J]. Building Environmen, 2007, 42; 1770-1777

[11] MANU SANTHANAM, COHEN M., OLEKJ. Differentiating sea water and ground water sulfate attack in Portland cement mortars[J]. Cement Concrete Research, 2006, 36(12), 2132-2137

[12] KOUROUNIS S, TSILIVIS S, TSAKIRIDIS P E, Papadimitriou G D, TSIBOUKI Z. Properties and hydration of blended cements with steelmaking slag[J]. Cement Concrete Research, 2007, 37; 815-822

[13] SHETTY M S, Concrete Technology (S. Chand and Co. Ltd, New Delhi)[B] (2004)

[14] MOLLAHM Y A, KESMEZM, COCKE,D L. An FTIR and XPS investigation of the effects of carbonation on the stabilization/solidification of cement based systems Portland type V with Zinc[J]. Cement Concrete Research, 1993, 23; 773784

[15] PALOMO A, FERNANDEZ-JIMENEZ A, KOVALCHUK G,ORDONEZ L M, NARANJO M C[J].Chemical stability of cementitous materials based on metakaolin. Cement Concrete Research, 1999, 29(7): 997-1004

[16] OMotoso O E, IVEY D G, MIKULAR. Containment mechanism oftrivalent chromium in tricalcium silicate[J]. J. Haz. Mater, 1998,60: 1-28

[17] MOLLAH M Y A, PALTA P, THOMAS HESSR. Chemical andphysical effects of sodium lignosulfonate superplasticizer on the hydration of Portland cement and solidification/ stabilization consequences[J]. Cement Concrete Research, 1995, 25(3): 671-682

[18] ROJAS M F. Study of hydrated phases present in a metakaolin-lime system cured at $60^{\circ} \mathrm{C}$ and 60 months[J]. Cement Concrete Research, 2006, 36;827-831

[19] TAYLORH W F, Cement Chemistry (Acadamic Press, Inc, New York) (1990)

[20] HARCHAND K S, KUMAR R, SHARMAK, Mossbauer and $\mathrm{X}$-Ray investigations of some Portland cements[J]. Cement Concrete Research, 1984, 14: 170-176

[21] MEDVESCEKS, GABROVSEKR, KEUCIC V, MEDENA. Hydration products in water suspension of Portland cement containing carbonates of various solubility[J]. Acta Chimica Slovonica 2006, 53; 172-179

[22] MORSY M S. Effect of temperature on hydration kinetics andstability of hydration phases of metakaolin-lime sludgesilica fumesystem[J]. Ceramics Silikaty, 2005, 49;225-229

[23] MONTGOMERYDM,SOLLARS C J, PARRY R, TARLING, S E,BARNESP,HENDERSONE. Treatement of organic contaminated industrial wastes using ement-based stabilizationa/solidification- I - microstructural analysis of cement - 
organic interactions[J]. Waste Management Research, 1991, 4: $113-11$

[24] BRUCKNER A, LUCK R, WIEKER W, WINKLER A, ANDREAE C, MEHNER $H$. Investigation of redox reactions proceeding during the hardening process of sulfide containing cement[J]. Cement Concrete Research, 1992, 22: 1161-1169
[25] LUBOMIR LAPCIK and ZDENEK SIMEK Jr. Electron paramagnetic resonance study of dry cements[J]. Cement Concrete Research, 1996, 26(2); 237-242

[26] SAMBASIVA RAO P. Single crystal EPR study of Fe(III) doped magnesium potassium Tutton's salt. Part $3[\mathrm{~J}]$. Spectra Chemica Acta Part A. 1996, 52; 1127-1134 